\title{
Application of Beetroot as Natural Coloring Pigment and Functional Ingredient in Dairy and Food Products
}

\author{
Gajanan P. Deshmukh ${ }^{1}$, Priyanka ${ }^{1}$, Rohit Sindhav ${ }^{2}$ and Naveen Jose ${ }^{2}$ \\ ${ }^{1}$ ICAR- National Dairy Research Institute, SRS, Bengaluru, India \\ ${ }^{2}$ College of Dairy Science, Amreli, Gujarat, India \\ *Corresponding author
}

\section{A B S T R A C T}

\section{Keywords}

Beetroot, Natural coloring pigment, Dairy and food

Products

Article Info

Accepted:

15 November 2018

Available Online:

10 December 2018
Food color is one of the parameters impacting food quality and consumer acceptance to a significant level. Synthetic food colors are being used in many food products which are a major concern to human health, having allergic and carcinogenic affects. Therefore, efforts are being made to use natural food colorants from natural sources such as turmeric, saffron etc. Beetroot is one such material which is a source of betalain and is a rich source of many bioactive and phytochemical compounds which are known to provide several health benefits. Beetroot has numerous medicinal properties such as anti-oxidant, anti-hypertensive, anti-microbial, antiinflammatory, hepato-protective, anti-hyperglycaemic, anti-cancer and diuretic. Beetroot juice and extract has wide range of application in many beverages, dairy products, cereals jams, jellies, candies, ice cream, yoghurt, sauces and processed meats This paper reviews the health benefits of beetroot and the possibility of its usage as a source of natural color for dairy and food industry.

\section{Introduction}

Color of the food is the main feature regards to consumer attraction and it acts as an indicator of quality and acceptability (Azeredo, 2008). Over the last few decades a large number of synthetic colorant is used in food products as coloring ingredient of food industry which cause severe health problem to the consumer e.g. carcinogenic effect. The use of synthetic red colorants as additives in food have been restricted by official regulations of the EU and the USA due to their possible adverse effects on human health (Tsuda et al., 2001). So, lots of efforts are going on for use of natural food (biocolorants) color like betalain (betanin and betacyanin) to be used in dairy and food product. 
Beetroot is a root crop belonging to Chenopodiaceae family and is commonly used as a salad in Indian Meals as well as for preparation of many culinary dishes. Its juice is also known to be healthy for sports persons. Beetroot is rich in several other bioactive compounds that may provide health benefits, particularly for disorders characterized by chronic inflammation, it also significantly reduce systolic and diastolic blood pressure. Beetroot is a rich source of phytochemical compounds that includes ascorbic acid, carotenoids, phenolic acids and flavonoids. Beetroot is also one of the few vegetables that contain a group of highly bioactive pigments known as betalains. The functional bioactive compound and natural coloring pigment present in beetroot opens a new opportunity in dairy and food industry to developed natural colored based functional dairy and food products.

\section{Beetroot varieties}

Several beetroot varieties exist (Table 1), among those the most outstanding ones are the red (beetroot) and the white beet (sugar beet). Both are very rich in sugar which is much more assumable than that of the sugar cane. They are also very rich in starch. Both possess eatable roots and their leaves can be used as a vegetable. Being much more flavorful, the red beet is the one that is generally dedicated to human feeding as while the white one is dedicated fundamentally to the production of sugar or the animal feeding (Anonymous, 2015a).

\section{Health benefits of beetroot}

Recently, beetroot is gaining popularity as a 'super food' due to its health beneficial value. Some of the major health benefits of beetroot are as follow
Lower blood pressure and increased blood flow.

It is helpful in tumor reduction, decrease the risk of obesity and overall mortality, diabetes, heart disease and promotes healthy hair, increase energy, and overall lower weight.

Several parts of beet root has numerous medicinal properties such as anti-oxidant, antihypertensive, anti-microbial, antiinflammatory, hepato-protective, antihyperglycaemic, anti-cancer and diuretic.

Beetroot juice improves oxygenation to the brain, slowing the progression of dementia in older adults.

Due to its high fiber content, it prevents constipation and promotes regularity for healthy digestive tract (Tulp and Bohlin, 2004; Anonymous, 2015c).

It helps to preserve brain function with nitrates that improve blood flow and beet having the ability to increase the production of Glutathione naturally in body, that compound helps to prevent colon cancer (Anonymous, 2015d).

\section{Nutritional value of beetroot}

The nutritional value of beetroot juice is very high due to its high content of carbohydrate, folate, fiber, iron, nitrate, manganese, potassium, vitamin $\mathrm{C}$ and in addition to that free fat, low in calories, inexpensive and beets are available throughout the year. Beets are fiber rich and have high concentration of antioxidant Vit. C, foliates, iron, manganese and magnesium (Table 2).

\section{Utilisation of beetroot in dairy and food products}

Beetroot Color is available in the form of powder which may be tray dried or spray dried and beetroot juice prepared by vacuum concentration (Table 3). 
Table.1 Taxonomical classification of beetroot

\begin{tabular}{|l|l|l|}
\hline Kingdom & $:$ & Plantae \\
\hline Subkingdom & $:$ & Tracheobionta \\
\hline Super division & $:$ & Spermatophyta \\
\hline Division & $:$ & Magnoliophyta \\
\hline Class & $:$ & Caryophyllidae \\
\hline Subclass & $:$ & Caryophyllates \\
\hline Order & $:$ & Chenopodiaceae \\
\hline Family & $:$ & Beta \\
\hline Genus & $:$ & B. vulgaris \\
\hline Species & & \\
\hline
\end{tabular}

Table.2 Composition of beetroot

\begin{tabular}{|l|l|l|l|}
\hline Constituent & Per cent & Constituent & Per cent \\
\hline Water & 87.5 & Phosphorus & $40 \mathrm{mg}$ \\
\hline Energy & $43 \mathrm{kcal}$ & Calcium & $16 \mathrm{mg}$ \\
\hline Fat & 0.17 & Magnesium & $23 \mathrm{mg}$ \\
\hline Protein & 1.61 & Iron & $0.80 \mathrm{mg}$ \\
\hline Carbohydrates & 9.56 & Zinc & $0.35 \mathrm{mg}$ \\
\hline Fibre & 2.8 & Vitamin C & $4.9 \mathrm{mg}$ \\
\hline Potassium & $325 \mathrm{mg}$ & Vitamin B2 & $0.04 \mathrm{mg}$ \\
\hline Sodium & $78 \mathrm{mg}$ & Vitamin B6 & $0.067 \mathrm{mg}$ \\
\hline Vitamin A & $36 \mathrm{IU}$ & Folacin & $109 \mathrm{mcg}$ \\
\hline Vitamin E & $0.30 \mathrm{mg}$ & Niacin & $0.334 \mathrm{mg}$ \\
\hline
\end{tabular}


Table.3 Utilisation of beetroot in dairy and food products

\begin{tabular}{|c|c|c|}
\hline Aution & Product & Description \\
\hline $\begin{array}{l}\text { Bandyopadhyay et } \\
\text { al., } 2007\end{array}$ & $\begin{array}{l}\text { Carrot } \\
\text { fortified milk }\end{array}$ & $\begin{array}{l}\text { Studied the effect of beet root extract along with honey on } \\
\text { quality attributes (acidity, pH, free fatty acid level and } \\
\text { sensory) and carotene retention of carrot fortified milk } \\
\text { product during storage at } 30^{\circ} \mathrm{C} \text {. }\end{array}$ \\
\hline $\begin{array}{l}\text { Junqueira- } \\
\text { Goncalves et al., } \\
2011\end{array}$ & C & 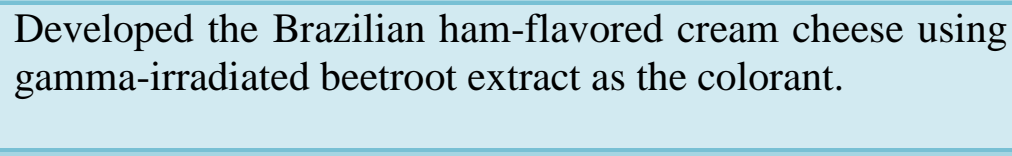 \\
\hline Isabelle et al., 2008 & $\mathrm{C}$ & $\begin{array}{l}\text { Studied the effect of Beetroot betalains incorporated } \\
\text { Petitsuisse cheese stored at } 6 \pm 1^{\circ} \mathrm{C} \text { for } 40 \text { days in light- } \\
\text { impermeable packaging on pigment stability by } \\
\text { determining half-life time and percentage color retention. }\end{array}$ \\
\hline $\begin{array}{l}\text { Kavitkar et al., } \\
2017\end{array}$ & Lassi & Jilized of beetroot extract as coloring agent in Lassi. \\
\hline $\begin{array}{l}\text { Kavitkar et al., } \\
2017\end{array}$ & 1 & . \\
\hline $\begin{array}{l}\text { Manoharan et al., } \\
2012\end{array}$ & $\begin{array}{l}\text { Strawberry } \\
\text { flavored ice } \\
\text { cream }\end{array}$ & $\begin{array}{l}\text { natural coloring agent for } \\
y \text { scored of the resultant }\end{array}$ \\
\hline Kha & & L.) juice \\
\hline Rach & B & $\begin{array}{l}\text { Formulate beverages by incorporating beetroot juice } \\
\text { concentrate. }\end{array}$ \\
\hline $\begin{array}{l}\text { Jayalalitha et al., } \\
2012\end{array}$ & $\begin{array}{l}\text { sed } \\
\text { ge }\end{array}$ & $\begin{array}{l}\text { A dairy based biobeverage containing higher vitamin A } \\
\text { and iron content was prepared with beetroot (Beta } \\
\text { vulgaris) juice, carrot juice and dates extract. }\end{array}$ \\
\hline Yo & & hilus and other \\
\hline Fla & $\mathrm{P}_{1}$ & $\begin{array}{l}\text { alled Proviva using fermented } \\
\text { and beetroot juice. }\end{array}$ \\
\hline ola et al., & ghurt & ristics of goat \\
\hline $\begin{array}{l}\text { Kamate } \\
\text { andPadghan, } 2018\end{array}$ & ey & $\begin{array}{l}\text { Utilized the beetroot extract for production of beetroot } \\
\text { whey beverage by using } 20 \text { per cent beetroot extract in } 80 \\
\text { per cent paneer whey on weight basis. }\end{array}$ \\
\hline $\begin{array}{l}\text { Vanajakshi et al., } \\
2015\end{array}$ & $\begin{array}{l}\text { A probiotic } \\
\text { beverage }\end{array}$ & $\begin{array}{l}\text { Developed probiotic beverage made with one part } \\
\text { ofmoringa leaves paste and two parts of beetroot juice } \\
\text { fermented with lactobacillus plantarum and enterococcus } \\
\text { hirae. }\end{array}$ \\
\hline $\begin{array}{l}\text { Martinez et al., } \\
2015\end{array}$ & $\begin{array}{l}\text { Beetroot- } \\
\text { orange juice } \\
\text { powder }\end{array}$ & $\begin{array}{l}\text { Developed beetroot orange juice powder by spray drying } \\
\text { and studied its functional properties, color and betalain } \\
\text { content. }\end{array}$ \\
\hline
\end{tabular}




\begin{tabular}{|l|l|l|}
\hline Kakade et al., 2015 & $\begin{array}{l}\text { Cereals based } \\
\text { extruded } \\
\text { product }\end{array}$ & $\begin{array}{l}\text { Optimized the process of cereals based extruded product } \\
\text { by utilization of beetroot leaves powder using RSM }\end{array}$ \\
\hline $\begin{array}{l}\text { Chaudhari and } \\
\text { Nikam, 2015 }\end{array}$ & Beetroot jelly & $\begin{array}{l}\text { Standardized the process for manufacturing of beetroot } \\
\text { jelly using 2 per cent pectin, 0.5 per cent citric acid and 61 } \\
\text { per cent sugar. }\end{array}$ \\
\hline Reddy et al., 2014 & RTE Snacks & $\begin{array}{l}\text { Developed the extruded ready to eat snacks using corn, } \\
\text { black gram, beetroots and tuber flour blends in a } \\
\text { proportion of 60-80: 20:20 respectively and moisture was } \\
\text { adjusted to 17-20 per cent. }\end{array}$ \\
\hline $\begin{array}{l}\text { Pinki and Awasthi, } \\
\mathbf{2 0 1 4}\end{array}$ & Cakes & $\begin{array}{l}\text { Developed the value added cakes by incorporating beetroot } \\
\text { powder and studied its Sensory and nutritional Value. }\end{array}$ \\
\hline Durge et al., 2014 & Ice-cream & $\begin{array}{l}\text { Utilized the prepared beetroot powder in ice-cream and } \\
\text { evaluated its different properties }\end{array}$ \\
\hline $\begin{array}{l}\text { Singh and Hathan, } \\
\mathbf{2 0 1 3}\end{array}$ & $\begin{array}{l}\text { Beetroot } \\
\text { candy }\end{array}$ & $\begin{array}{l}\text { Optimized the process for manufacturing of osmotically } \\
\text { dehydrated beetroot candy using response surface } \\
\text { methodology }\end{array}$ \\
\hline Rachitha, 2016 & $\begin{array}{l}\text { Shrikhand, } \\
\text { coconut } \\
\text { biscuit, } \\
\text { instant soup } \\
\text { mix and } \\
\text { besan burfi }\end{array}$ & $\begin{array}{l}\text { Developed the lime beet juice, amla beet juice, shrikhand, } \\
\text { coconut biscuit, instant soup mix and besan burfi using } \\
\text { spary dried beetroot powder and vacuum concentrated } \\
\text { beetroot juice concentrate. }\end{array}$ \\
\hline
\end{tabular}

Figure.1 Overview of potentially bioactive compounds in beetroot

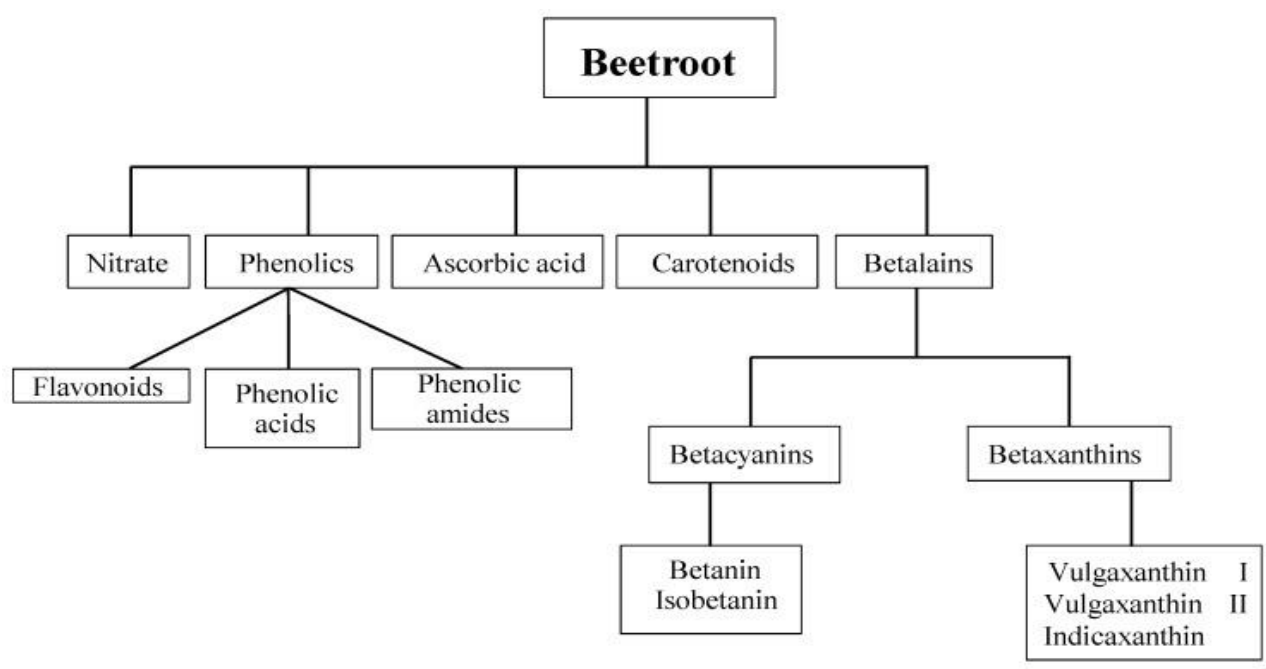

Source: Clifford et al., 2015

It has wide range of application in dairy and food product mainly as coloring agent and for production of value added functional food products. Beetroot extract is used in 
beverages, dairy products, cereals jams, jellies, candies, ice cream, yoghurt, sauces and processed meats are summarized below. In conclusion, beetroot is one of the oldest tuber root known to mankind and is used as therapeutic and functional food ingredients from ancient times. It is used as natural food coloring and functional food ingredients in many dairy and food products. Several research studies have shown that beetroot has numerous medicinal properties such as antioxidant, anti-hypertensive, anti-microbial, anti-inflammatory, hepato-protective, antihyperglycaemic, anti-cancer and diuretic. It also holds potential in therapeutic treatment for several pathological disorders. Beetroot is a rich source of wide range of functional compounds which opens a new door to food scientists and food industry for development of value added functional foods.

\section{References}

Anonymous (2015a). (Properties of beets www. Botanical-online.com/ commonbeet.htm).

Anonymous (2015 b). Effect of Temperature on pigment release by Beetroot.

Anonymous (2015c). http:// www.medical newstoday.com/articles/277432.php).

Anonymous (2015d). http://underground healthreporter.com/benefits-of-beetjuice).

Azeredo, H. M. C. (2008).Betalains: properties, sources, applications, and stability -a review. Int. J. Food Sci. Technol., 44: 2365-2376.

Bandyopadhyay, M., Chakraborty, R. and Raychaudhuri, U. (2007). Effect of beet and honey on quality improvement and carotene retention in a carrot fortified milk product. Inn. Food Sci. Emerg. Technol., 9: 9-17.

Chaudhari S.N. and Nikam, M.P. (2015). Development and Sensory Analysis of Beetroot Jelly. International Journal of
Science and Research (IJSR). 4(10): 827-830.

Clifford, T., Howatson, G., West, D. and Stevenson, E. (2015). The potential benefits of red beetroot supplementation in health and disease. Nutrients, 7(4): 2801-2822.

Damunupola, D.A.P.R., Weerathilake, W.A. D.V. and Sumanasekara, G. S. (2014). Evaluation of Quality Characteristics of Goat milk yoghurt incorporated with Beetrootjuice. International Journal of Scientific and Research Publications, 4(10): 2250-3153.

Duige K.V., Sawate A.R., Kshirsagar R.B., Taur A.T., Patil B.M., Mundhe S.S. and Kulkami S.P. (2014). Utilisation of Beetroot Powder as Natural Colorant in Ice-Cream. Indian Journal of Nutrition Dietetics, 51:400-407.

Flavera, C. P., Jose, L. P., Pandey, A. and Carlos, R. S. (2007). Trends in nondairy probiotic beverages. Food Res. Int. , 41: 111-123.

Jayalalitha, V., Elango, A. and Naresh Kumar, C. (2012). Development of a novel bio beverage Biofevita. Int. Res. J. Appl. Basic Sci., 3(5): 2867-2869.

Junqueira-Goncalves, M. P., Cardoso, L. P., Pinto, M. S., Pereira, R. M., Soares, N. F. and Miltz, J. (2011). Irradiated beetroot extract as a colorant for cream cheese. Rad. Phys. Chem., 80 (1): 114118.

Kakade S. B., Hathan B.S. and Neeha V.S. (2015). Utilization of Beetroot (Beta vulgaris L.) Leaves powder in cereals based extruded product International Research Journal of Engineering and Technology (DUET), 2(3):2153-2161.

Kamate, R. D. andPadghan, P. V. Studies on Sensory/Organoleptic Properties of Beetroot Whey Beverage International Journal of Current Microbiology and Applied Sciences ISSN: 2319-7706 Special Issue-7 pp. 3309-3315. 
Kavitkar, R. S., Rao, K. J., Mishra, D., Chavhan, B., Deshmukh, G. P. and Prajapati, R. (2017). Utilization of Beetroot Extract as Colouring Agent in Lassi. Int. J. Pure App. Biosci, 5(6): 295-299.

Kavitkar, R. S., Rao, K. J., Mishra, D., Chavhan, B., Deshmukh, G. P. and Prajapati, R. (2017). Utilisation of Beetroot Extract as Colouring Agent in Lassi. Int. J. Pure App. Biosci, 5(6), 295-299.

Manoharan, A., Ramasamy, D., Dhanalakshmi, B., Gnanalashmi, K.S. and Thyagarajan, D. (2012). Organoleptic evaluation of beetroot juice as natural color for strawberry flavor ice cream. Indian J. Med. Healthcare, 1(1): 2278-2286.

Pinki and Awasthi. (2014). Sensory and nutritional evaluation of value added cakes formulated by incorporating beetroot powder. International Journal of Food and Nutritional Sciences, 3(6): 145-148.

Rachitha, R. (2016). Development of value added food products by incorporating beetroot (Beta Vulgaris L.) (Doctoral dissertation, Vasantrao Naik Marathwada Krishi Vidyapeeth, Parbhani).

Rachitha, R., Nalwade, V. M., andShere, D.
M. (2016). Development of food products by incorporating beetroot (Beta vulgaris L.). Food Science Research Journal, 7(2):245-249.

Reddy. M. K., Kuna A., Devi, L. N., Krishnaiah N., Kaur C. and Nagamalleswari. Y. (2014). Development of extruded Ready-To-Eat (RTE) snacks using com, blackgram, roots and tuber flour blends. Journal of Food Science and Technology, 51(9):221-224.

Singh B. and Hathan B.S. (2013). Optimization of osmotically dehydrated beetroot candy using response surface methodology. International Journal of Food and Nutritional Sciences. 2(1):1521.

Tsuda, S., Murakarni, M., Kano, K., Taniguchi, K. and Sasaki, Y. F. (2001). DNA damage induced by red food dyes orally administered to pregnant and male mice. Toxicol. Sci., 61:92-93.

Tulp, M. and Bohlin, L. (2004) Unconventional natural sources for future drug discovery. DDT Vol. 9. (www.drugdiscoverytoday.com).

Yoon, K. Y., Woodams, E. E. and Hang, Y. D. (2005) Fermentation of beet juice by beneficial lactic acid bacteria. Lebensm.-Wiss. u.-Technol., 38:73-75.

\section{How to cite this article:}

Gajanan P. Deshmukh, Priyanka, Rohit Sindhav and Naveen Jose. 2018. Application of Beetroot as Natural Coloring Pigment and Functional Ingredient in Dairy and Food Products. Int.J.Curr.Microbiol.App.Sci. 7(12): 2010-2016. doi: https://doi.org/10.20546/ijcmas.2018.712.231 